\title{
The comparison of two different weaning trial methods for patients with chronic obstructive lung disease (COPD) in a cardiothoracic intensive care unit (ICU)
}

\author{
TA Ayazoğlu, A Baysal², A Özensoy², H Yilmaz³, THG Yilmaz ${ }^{3}$ \\ From ESICM LIVES 2015 \\ Berlin, Germany. 3-7 October 2015
}

\section{Introduction}

Postoperative complications related to pulmonary and cardiovascular functions are higher in patients with chronic obstructive pulmonary disease (COPD) after cardiac surgery (1).

\section{Objectives}

The two different weaning trial methods including $\mathrm{T}$ tube and biphasic positive airway pressure (BiPAP) was compared in patients with COPD after failed extubation postoperatively.

\section{Methods}

After cardiac surgery, 188 patients with COPD under mechanical ventilation for greater than 24 hours and failed extubation were prospectively randomized to receive a $\mathrm{T}$-tube spontaneous breating trial $(\mathrm{n}=94)$ or 2-hour BIPAP trial $(\mathrm{n}=92)$. Two patient who refused to complete two-hour BIPAP was excluded. The trial procedure was repeated after 24 hours if patients were failed to be weaned in the first attempt in case they fulfilled the weaning criteria. Signs of a low 2-hour trial tolerance; included spontaneous respiratory rate > $25 /$ min, $\mathrm{SatO} 2<90 \%$, FiO2 $\leq 0.4$, heart rate $>140 /$ min (or more than $20 \%$ change from the initial heart rate), systolic blood pressure $>200 \mathrm{~mm} \mathrm{Hg}$ or $<80 \mathrm{~mm} \mathrm{Hg}$, $\mathrm{Pao} 2 \leq 60 \mathrm{~mm} \mathrm{Hg}, \mathrm{pH} \leq 7.30$, and restlessness. ([1]). BIPAP was applied in spontaneous breathing at inspiratory positive airway pressure of 8 to $12 \mathrm{cmH} 2 \mathrm{O}$ and expiratory positive airway pressure of 4 to $6 \mathrm{cmH} 2 \mathrm{O}$.

'Medeniyet University Goztepe Research and Training Hospital,

Anesthesiology and Reanimation, Istanbul, Turkey

Full list of author information is available at the end of the article
Arterial blood gas values $(\mathrm{pH}, \mathrm{PaCO} 2, \mathrm{PaO} 2, \mathrm{SaO} 2$, $\mathrm{HCO} 3)$ were collected. The weaning outcome was assessed depending on the following parameters: extubation success, mechanical ventilation duration, duration of intensive care unit (ICU) stay, reintubation rate, and mortality rate.

\section{Results}

Two-hour trial failed in 41 (44\%) patients in T-tube and $40(43 \%)$ patients in BIPAP group $(\mathrm{p}=0.871)$. Of patients in whom weaning failed, $33(54 \%)$ in the T-tube group and 29 (73\%) in the BIPAP group were successfully extubated $(\mathrm{p}<0.001)$. Mechanical ventilation lasted significantly longer in $\mathrm{T}$ tube than in BIPAP group (187 hours vs 163 hours, respectively, $\mathrm{p}<0.001)$. Also, patients in T-tube group ICUstay time was more than patients in BIPAP group (238 hours [interquartile range 208-274] vs 205 hours [200-255], respectively, p < $0.001)$. Reintubation was required in $9(27 \%)$ and 5 (17\%) patients in T-tube and BIPAP group, respectively $(\mathrm{p}<0.001)$ and 30 -day mortality was $9(9.6 \%)$ and $6(7 \%)$ patients, respectively $(\mathrm{p}>0.05)$.

\section{Conclusions}

After cardiac surgery, patients with COPD who failed the 2-hour spontaneous breathing trial show successful extubation and improved postoperative outcomes as well as diminished ICU stay with the use of BIPAP method rather than $\mathrm{T}$ tube method for weaning from mechanical ventilation and for these reasons BIPAP shows a promising weaning modality for mechanically ventilated COPD patients after cardiac surgery. 


\section{Authors' details}

${ }^{1}$ Medeniyet University Goztepe Research and Training Hospital,

Anesthesiology and Reanimation, Istanbul, Turkey. ${ }^{2}$ Kartal Kosuyolu Research and Training Hospital, Anesthesiology and Reanimation, Istanbul, Turkey.

${ }^{3}$ Iskenderun State Hospital, Anesthesiology and Reanimation, Hatay, Turkey.

Published: 1 October 2015

\section{Reference}

1. Matic I, Danic D, Majeric-Kogler V, Jurjevic M, Mirkovic I, Vucinic NM:

Chronic Obstructive Pulmonary Disease and Weaning of Difficult-toWean Patients from Mechanical Ventilation: Randomized Prospective Study. Croat Med J 2007, 48(1):51-58.

doi:10.1186/2197-425X-3-S1-A167

Cite this article as: Ayazoğlu et al:: The comparison of two different weaning trial methods for patients with chronic obstructive lung disease (COPD) in a cardiothoracic intensive care unit (ICU). Intensive Care Medicine Experimental 2015 3(Suppl 1):A167.

\section{Submit your manuscript to a SpringerOpen ${ }^{\circ}$ journal and benefit from:}

- Convenient online submission

- Rigorous peer review

- Immediate publication on acceptance

- Open access: articles freely available online

- High visibility within the field

- Retaining the copyright to your article

Submit your next manuscript at $>$ springeropen.com 